\section{Seyama Sultana}

School of Business and Economics,

United International University Dhaka, Bangladesh

\section{Abdul Momen}

Department of Business Administration, East West University, Dhaka, Bangladesh momeniium@gmail.com

\title{
International Student Satisfaction and Loyalty: A Comparative Study of Malaysian and Australian Higher Learning Institutions
}

Abstract: Purpose - Factors affecting international student satisfaction and loyalty are crucial for higher learning institutions of Malaysia as the country wants to become a global education hub. The purpose of this paper is to determine the most contributing factors affecting the level of international student satisfaction and how these factors affect loyalty of the students. These factors are academic issues, economic considerations, image and prestige and infrastructure of the university. The study involved the same research in Australia in order to compare situations in these two nations.

Methodology - A structured questionnaire was used to collect data to determine the significant factors affecting the level of satisfaction and loyalty of international students of Malaysian and Australian public universities. 
Findings - The primary results demonstrated that towards international students, academic issues and economic considerations are more important than rest of two other factors in Malaysia where in Australia image and prestige are quite significant.

Value - This study contributes to the research of Malaysian educational field and research of Malaysia as a global educational hub as it involves comparison with a developed country like Australia.

Keywords- Student satisfaction, loyalty, higher learning institutions, academic issues, economic considerations

\section{Introduction}

An emerging source of foreign exchange earning can be Malaysia's ever growing and advancing education sector. The country is earning foreign exchange from this segment. And it can earn more from this if it patronages the sector. The global demand for international higher education may increase to more than 3.5 million by 2025 (Wilkins, Balakrishnan \& Huisman, 2012). In another study, it is mentioned that the demand for international higher education may increase from 1.8 million customers to 7.2 million by 2025 where Malaysia, India and China represent $70 \%$ of this growth (Shahzad etal., 2016).

Malaysian education is well standard but needs to improve further. The international demand for higher education will increase dramatically with both opportunities and challenges to higher education institutions all around the world (Arambewela \& Hall, 2009). Malaysia is trying to become a regional centre for educational hub (Jalali, 2011).

Though everything is positive for Malaysian education there remain some negative facts. Excluding the international students coming to Malaysia, even the Malaysian students are seeking educational services in other countries despite the industry efforts in developing educational infrastructure (Sohail and Saeed, 2003). Once in Malaysia National Accreditation Body rejected 40 programs of private universities because of poor course configuration (Bakar, 2004). Further Rajah and Nadarajah 
(2000) mentioned, "Don't be surprised if a student takes one of you to court for not teaching properly." In these days the fact is students cannot wait for any change to take place rather they try to find channels to give their complains (Jalali, 2011).

In most of the education institutions of Malaysia, staffs are not aware of their customer demand or the demand of students, though the authority is concerned (Kanij, Abdul Malek and Wallace, 1999).

In several Malaysian universities the international post graduate students have negative perception about the quality of education. The result of dissatisfaction occurs because the expectations of the students are not met by the universities regarding the quality of education (Shahzad et al., 2016).

Hence arises, the importance of international student satisfaction and their loyalty behaviour. The more satisfied the international students are the more they will spread good words of mouth and the more students from abroad will come. It will be just like the pull strategy of marketing rather the push strategy. In service marketing pull strategy can be more effective as it will call for services from the customers or consumers rather pushing the services from the institutions. In education this strategy will work best. The international students of Malaysia themselves can become good advertisement source and at the same time the country will prosper one step ahead by improving the service quality of education (Carter and Yeo, 2016).

Therefore the factors that affect international student satisfaction and loyalty have great value to find out. Previous researches on Malaysian education mainly focused on specific issues but did not include all significant factors together in the same research and thus the overall picture is not clear regarding which factors are most contributing for international student satisfaction and loyalty. Again most studies are concentrated on local students rather than international students. Hence, the research emphasized in determination of the factors affecting the level of international student satisfaction and it measures how it affects their loyalty in Malaysia (Shahzad et al., 2016). Therefore the factors that affect international student 
satisfaction and loyalty have great value to find out. Again if it is possible to compare this with a developed nation like Australia, deeper information will be gained in order to find some common issues to compete and some uncommon issues to convert into competitive advantages. Australia is not only a highly developed country but also the country has achieved third position in the world for its high quality university education in the ranking of University World News (Kerry, 2008).

Therefore the research emphasized in determination of the factors affecting the levels of international student satisfaction and it measured how it affected their loyalty in both countries Malaysia and Australia. Afterwards the study compared the results gained from two different data sets.

\section{Context of this study}

The study suggests the basic dimensions of the satisfaction and loyalty behaviour of international students of Malaysian universities and which sectors need to improve, change or maintain and what are the other facilities can be added for them to enhance their satisfaction. In order to get this information, this study has included public universities of Malaysia. After the independence of Malaysia, Ministry of Education converted the old system into a new unified national education system. It focused on economic progress, national aspiration and technological development (Education in Malaysia, 2001). The objectives of higher education may include: 1. Advancing national integration; 2 . Meeting the demand of high level manpower; 3. Improving modern proficiency and technology. Many higher learning institutions from USA, Canada, UK, Australia, France, Germany and New Zealand have offered franchised degree programs with Malaysian higher education institutions (Ministry of Higher Education (MOHE), 2010). According to universitymalaysia.net, Malaysia has become a lucrative study destination because of its international reputation and world standard education orga- 
nism. There are 50,000 international students who have come to Malaysia from more than 100 countries. They are studying in different education institutions like schools, colleges, private and public universities, foreign universities branch campuses. Including short-term and professional courses, diplomas, bachelor degree and other post-graduate studies such as master's degrees or doctoral degrees, they have enrolled (Carter and Yeo, 2016).

But influencing knowledge of the students positively is not the only goal of educational institutions rather they should enhance students' total development (Astin, 1993). In order to do so education institutions should continuously collect information about student satisfaction, which is mentioned as an 'ever present campus variable' by many authors (Betz, Menn, Starr \& Klingensmith, 1971). It is also mentioned as key outcome of education (Astin, 1993) or 'quality enhancement tool', (Harvey, Plimmer, Moon \&Geall, 1997). Sometimes decision makers think whatever the services they provide students will be satisfied. But this is not the case at all. Student satisfaction specially, international student satisfaction is a vital issue. If the students are not satisfied they will be de-motivated in study. The after effect will be serious. The unsatisfied foreign students will not only spread bad words of mouth about any university rather they will negatively advertise the country. In this way not only education sector but also tourism sector will be hampered badly and overall international image of Malaysia will be damaged. Thus international student satisfaction and their loyalty behaviour should be monitored and universities should work accordingly. Based on some research papers, facts may include some kind of dissatisfaction among the foreign students in Malaysia. In this group of dissatisfied international students, some students are quite aggressive and spread bad words of mouth about specific institutes or even about the country and are searching for other university or country to switch; some of them are trying to solve problems by complaining or in other ways and on the other hand, some students are just neutral in their actions but still dissatisfied. This is a big problem for the education industry of the country and its international 
image. Thus in order to solve this problem, decision makers or the authority must learn which factors play the contributing roles to satisfy foreign students of Malaysia and ultimately impact on their loyalty behaviour.

Adjustment of the foreign students in another country can be another reason of dissatisfaction. Black and Gregersen (1991) define adjustment as the degree of any person's physiological adaptation and comfort in a new setting. Studying in a foreign country can be stressful and it requires different types of adjustments. Dissatisfaction may originate from failure in proper adjustment. Adjustment can vary from culture to culture and country to country. Another significant issue is that the adjustment should take place in different universities differently in the same country. Thus adaptation or adjustment in a specific university of foreign country is also important (Carter and Yeo, 2016).

Many students are quite comfortable in the institutions of their own countries but face difficult problems in the whole new environment of an institute in the foreign land. The differences may include communication system, infrastructure, socio-economic situation, teacher-student relationships, relationships between and among other foreign and local students (Shekarchizadeh et al., 2011). According to Ham (2003), dissatisfaction of foreign students may cause several consequences like, 1. It will hamper the intention of repurchase or international student loyalty; 2. Foreign students will not recommend the university to others who seek advice from them; 3 . It may cause switching from one university to another (Shahzad et al., 2016).

Every organization seeks loyal customers which can be gained through by customer satisfaction. Customer satisfaction for any institution is as important as air for human life (Jalali, 2011). Service industry is spreading and advancing at a very high rate. Thus this industry has become more competitive than ever before. As a result consumers of services, their preferences and their satisfaction have become very crucial for the success of the companies and institutions involved in the industry (Carlborg, Kindström \& Kowalkowski, 2014). Among the sectors of services education 
service has great value. Higher education sector has become increasingly competitive as local and foreign students are more concerned than before and they expect to fund for themselves for their study (Angell et al, 2008). Therefore student satisfaction is a crucial issue in this industry. In this education industry it has become very difficult to create competitive advantages (Cubillo-Pinilla et al, 2009). Educational institutions are searching new ways to create point of difference and competitive advantages as the domestic and international demand and competition have increased (Rasli and Naim, 2005). In order to retain tuition based returns, measuring service quality and student satisfaction are two essentials (Angell et al, 2008). At last as per the theory of service another most vital issue is experience based out come from where it is clear that the service quality should be ensured and it should fulfil the requirements of the consumers and only then the outcome will be up to the mark(Wu, Yeh \& Woodside, 2014). Therefore in order to get good quality students, education quality should be ensured as per the demand and only by their satisfaction their quality can be ensured. All the relevant researches are mostly conducted in western countries hence the results are quite different from Malaysia. To get better insight of the situation, here a comparison is entailed. As Australian education system is quite comparable with that of Malaysia and as the country Australia has achieved a great place in international education thus this research involved Australia for comparison.

\section{Theoretical discussion}

In the theory of customer satisfaction it is mentioned that every customer or consumer has a level of expectation related with any product or service. If any company or institute can meet the expectation of its customers or consumers they will be satisfied. If it fails to do so then the customers will be disappointed and unsatisfied. If the company can provide more than their expectation the customers will be delighted (Kotler \& Armstrong, 
2001). In today's competitive world one of the major intentions of companies is to delight their customers.

Beside customer satisfaction customer loyalty should be analyzed. According to Anderson (1998), there is significant relationship between satisfaction and loyalty where dissatisfied customers conduct more disloyal behaviour than satisfied customers. Satisfied customers have intention to recommend the product or service to others and re-purchase the same brand of product or service or re-purchase it from the same company or service provider (Wiedemann and Anderson, 1985). If a customer has a good experience with any product or service he or she will be encouraged to share his/her experience or satisfaction to other people (Parasuraman et al, 1991; Stauss and Neuhaus, 1997; Pizam and Ellis, 1999). It is clear that there is significant positive relationship between customer satisfaction and loyalty (Najib et al, 2011).

\subsection{Academic issues and student satisfaction and loyalty}

Based on the requirements of students teaching guidelines and materials should be fixed. Thus good teaching is essential to satisfy any student and meet his or her basic needs and demands. Certain vital matters help a student to define the quality of education of any institution. All these can be varieties of courses with world class syllabus, promptness of admission office etc. In this case at first any student or foreign student searches whether the specific university has any suitable program same or relevant according to his or her expectation. Another major thing is international students try to find information about the standard of education, whether it is up to the mark or not and whether it is comparable with the world standard or not. Thus this sector should be given great value to improve its efficiency to make the students satisfied and loyal (Jalali, 2011).

Students come to any university after they can gain enough positive information about the education quality of that institute. On the other hand, 
it can be said that the first and foremost goal of students is to get good quality or well standard education (Kamal et al., 2010).

According to Chen, Haiso and Lee (2005), student loyalty is very much affected by academic activities, knowledgeable faculty and specialized courses. Here student expectation includes faculty members to improve the knowledge of the students, faculty professional expertise and their ability to demonstrate.

From the above discussion several hypothesis can be made like:

$\mathrm{H}$ : Academic issues have positive influence on international student satisfaction

$\mathrm{H}$ : Academic issues have direct positive influence on student loyalty behaviour

$\mathrm{H}$ : Student satisfaction has mediating effect between academic issues and student loyalty behaviour

\subsection{Economic considerations and student satisfaction and loyalty}

International students select universities based on the availability of fund or it can be said that fund becomes a major contributing factor of their university selection decision and satisfaction. Funding is also important to retain the students. Fund can come from different sources and in different forms. It can be scholarships from any university or outside sources or there can be working facilities provided by the universities with expected salary. Sometimes students are also concerned about the full free studentship or some kinds of concession on their fees. All these information are important to any new comer (Abe et al., 1998).

Economic considerations, casual jobs, cost of living are directly involved in the macro level of economic factors. These can affect in a great deal in the satisfaction level of any international student. These are more difficult and 
uncontrollable variables for foreign students, rather than local students as foreign students live in an unfamiliar environment (Arambewela \& Hall, 2009).

Students with funding needs do not move from their country at under graduate level. These types of students are found generally at Masters and PhD programs. Thus these students try to get information regarding the funding facilities of individual universities. Based on this issue they choose educational institution and sometimes destination country (Burke, 1986).

Based on the mentioned literatures few hypotheses can be made and these are:

$\mathrm{H}$ : Economic considerations have positive influence on international student satisfaction

$\mathrm{H}$ : Economic considerations have direct positive influence on student loyalty behaviour

$\mathrm{H}$ : Student satisfaction has mediating effect between economic considerations and student loyalty behaviour

\subsection{Image and prestige and student satisfaction and loyalty}

Image and prestige issue is more important to any foreign student than a local student. Generally foreign students take or try to take admission in those universities which are more renowned and famous. It can be measured in three different dimensions. Image and prestige may vary in the host country, home country or in the world as a whole. Any foreign student values image and prestige of any educational institutions in which he or she wants to study. After that the student may be concerned about the image of that particular university in its home country and international ranking or brand image also play great role in the level of satisfaction of the international students and it ultimate affects their loyalty (Arambewela, 2008).

As image and prestige of any university can create better career opportunities for the students thus it is very crucial for international stu- 
dents especially for the post graduate students. But gaining image and prestige internationally as an educational institution is not an easy task. It requires great commitment, excellent delivery of education and quality research. Only because of image and prestige any student can choose the same institute if there is any possibility of further study (Arambewela \& Hall, 2009). Thus image and prestige have significant impact on the international student loyalty behaviour.

Great emphasis should be given on this issue as it not only affects the level of satisfaction of foreign students but also seriously influences their choice of educational institutions or university and sometimes their study destination (Mullins et al. 1995).

The retention of current students and attraction of potential students depend greatly on the image of any university (Arambewela \& Hall, 2009).

According to the literatures several hypotheses which can be made are:

$\mathrm{H}$ : Image and prestige have positive influence on international student satisfaction

$\mathrm{H}$ : Image and prestige have direct positive influence on student loyalty behaviour

$\mathrm{H}$ : Student satisfaction has mediating effect between image plus prestige and student loyalty behaviour

\subsection{Infrastructure and student satisfaction and loyalty}

The environment in which students study and the surrounding of university must be seriously considered. In physical environment there are certain factors such as lighting, layout, appearance of building, classrooms, and overall cleanliness all these are important for student satisfaction and allegiance (Jalali, 2011). The infrastructure, its appropriateness and even the attractiveness are also important to any student especially to a foreign student. Thus uses of modern equipment and technology, visually appealing physical facilities, visually appealing materials etc. all are contri- 
buting factors in the concern of student satisfaction and loyalty (Shekarchizadeh et al., 2011).

Student satisfaction depends on various types of factors. It may start from the lecturers to other services or facilities. In these services and facilities two forces can be mentioned like, technology access to computer facilities, availability of modern facilities. IT and other related services or facilities should be advanced and up to date to quench the thirst of modernization need of students. Universities should understand the expectations of students regarding appropriate learning environment (Arambewela \& Hall, 2009).

The importance of library to the academicians, students and all research fellows is great. Thus in the determination of international student satisfaction level, library facilities should be asked to confirm the adequacy and quality of this service. Here two key factors may include the quality and the quantity of books. Availability of required text books and other supportive books are very critical on which student satisfaction can be enhanced or totally damaged (Kiran, 2010).

Residential requirement is regarded as an essential element provided by universities to satisfy the students. To achieve social solidity student housing should be well planned and well standard which will facilitate desirable educational outcomes from the students (Hassanain, 2008).

International students expect comfortable accommodation facility should be provided by universities at reasonable cost. Here another important point is that students expect this sort of accommodation should be provided by the universities whenever it is needed(Arambewela \& Hall, 2009).

As per the related literatures the hypotheses those can be made are:

$\mathrm{H}$ : Infrastructure has positive influence on international student satisfaction

$\mathrm{H}$ : Infrastructure has direct positive influence on student loyalty behaviour

$\mathrm{H}$ : Student satisfaction has mediating effect between infrastructure and student loyalty behaviour 


\subsection{Relationship between Student Satisfaction and Student Loyalty}

As the students are treated as consumers therefore the relationship between consumer satisfaction and consumer loyalty can be discussed here. Now a days it is very easy for the customers to switch as there are lots of options they can do it with minimum effort and cost. Most of the cases it is easier to satisfy the current customers rather to gain new customers (Kotler \& Armstrong, 2001).

Customer satisfaction can be the minimum goal but not the ultimate one as more than this can be required sometimes. Customers should be delighted thus the service providers should give them more than their expectation. In this way over satisfied customers are needed to build loyalty.

Shekarchizadeh et al. (2011) has developed a model where it is clear that there is strong relationship between customer satisfaction and customer loyalty. Here company image and service quality affect customer satisfaction and customer satisfaction creates customer loyalty.

Therefore from the discussion the hypothesis can be made:

$H$ : International student satisfaction has positive influence on student loyalty

\subsection{Effect of country of origin}

In order to get deeper and rich information about the issue that is the factors affecting international student satisfaction towards loyalty behaviour can be compared between a developing country Malaysia with that of a developed nation Australia. Therefore the hypothesis is:

$\mathrm{H}$ : Country of origin (Malaysia/Australia) has moderating effect on international student satisfaction towards loyalty 


\subsection{Summary of the hypothesis}

$\mathrm{H} 1$ : Academic issues have positive influence on international student satisfaction

$\mathrm{H} 2$ : Economic considerations have positive influence on international student satisfaction

H3: University image and prestige have positive influence on international student satisfaction

H4: University infrastructure has positive influence on international student satisfaction

H5: International student satisfaction has positive influence on student loyalty

H6: Academic issues have direct positive influence on student loyalty

$\mathrm{H7}$ : Student satisfaction has mediating effect between academic issues and student loyalty

H8: Economic consideration has direct positive influence on student loyalty

H9: Student satisfaction has mediating effect between economic consideration and student loyalty

H10: Image and prestige have direct positive influence on student loyalty

H11: Student satisfaction has mediating effect between image plus prestige and student loyalty

H12: Infrastructure has direct positive influence on student loyalty

H13: Student satisfaction has mediating effect between infrastructure and student loyalty

H14: Country of origin (Malaysia/Australia) has moderating effect on international student satisfaction towards loyalty 


\section{Methodology}

The study was conducted from 2012 to 2016. Quantitative techniques are followed in modelling the analysis of the data. Data collection of the study is done through survey method. The research design is appropriate for this study for two reasons. First, it is difficult for the researchers to manipulate the variables (Emory and Cooper, 1991). Second, respondents cannot be easily assigned to treatment and control groups, as they are assigned in experimental studies.

Survey method for data collection and structural equation modelling for data analysis are well established and well accepted in the field of business and marketing. According to Malhotra (1999) to obtain accurate and complete information about the research problem, questionnaire is the most formalized tool. In addition survey method is the appropriate approach to examine the research hypotheses. The questionnaire has achieved the objectives of the study. With the help of this questionnaire information regarding the factors that affect international student satisfaction is gained and at the same time how their satisfaction affects their loyalty behaviour is focused.

Here random sampling is used to select the samples. Other than some sampling methods, random sampling has greater probability of obtaining a well representative sample. In random sampling method all elements in the selected population have an equal chance of being selected for the study (Gay and Airasian, 2003). Since the objectives of the study are to answer research questions that are related to a subgroup within the population, thus stratification technique is suitable for the current study. In 20 public universities questionnaires were distributed to the international students in Malaysia and Australia.

For the basic constructs and the variables as a whole, the questions of the study are derived from the literatures and the existing theories. Lascu, Ashworth, Gies and Omar (1995) argued that if numerical scales exceed 
5-point scale then it can be very complex for the respondents to make their judgement about a particular statement. Thus, in this study 5-point likert scale is used to measure the responses of the questions. The scale includes 5 different levels of responses like: 1- Strongly Disagree; 2- Disagree; 3- Neutral/Not Sure, 4- Agree, 5- Strongly Agree.

In this study exploratory factor analysis, confirmatory factor analysis and structural equation modelling were used to analyze data. Here the sampling units are the international students that study in different Malaysian and Australian universities. In this descriptive analysis, means, standards deviations, frequency distribution, and percentages etc. are included. Exploratory factor analysis measures the relationships of certain variables which affect the satisfaction of foreign students here. One variable can be treated as significant within one factor if the factor loading is greater than 0.5 and an eigenvalue equal to or greater than 1.0 Cronbach's alpha coefficient is used to test the reliability of the scale. CFA uses multivariate technique in order to confirm hypothesis or pre-determined relationships and it measures the significance level of any independent variable on the dependent variables (Hair et al., 2010). Before proceeding towards CFA there are certain essential tests to conduct. These may include correlation or communalities test, $\mathrm{KMO}$ and Barlett's test of adequacy. It may extend further to goodness of fit index, results of chi-square, degrees of freedom, p-value, reports of CMIN, Root-Mean Square Analysis (RMSEA), Comparative Fit Index (CFI) and Normed Fit Index (NFI), Tucker-Lewis Index (TLI) or non-normed fit index etc. Overall fit of data, content validity, convergent validity, discriminant validity, unidimensionality analysis, and reliability are essential to evaluate the adequacy of measurement model. It can be ensured by content validity that the measure includes representative set of items which describes the concept and also its adequacy.

In order to test the reliability of the scale Cronbach's alpha coefficient is used. The lower limit for Cronbach's alpha coefficient is .60 - .70 generally (Hair et.al, 1998). Further, to test the construct validity confirmatory 
factor analysis along with structural equation modelling is used. In social sciences SEM has become the most popular technique for data analysis (Hooper et al., 2008).

In this study, SEM is used to determine whether the estimated population covariance matrix of the research model is consistent with the sample or observed covariance matrix. If the model is adequate the parameter is able to estimate the regression coefficients, variances. The covariance produces an estimated matrix which is closed to the sample covariance matrix. Here overall closeness is evaluated primarily by various fit indices.

\section{Results and discussion}

It is clear that international students who study in Malaysia are quite comparable regarding gender. The percentage of male was 53.3\% and that of their counterpart female was $46.7 \%$. The study involved post graduate international students but majority of them was within 20- 29 years old but still $7 \%$ of them have fallen within the group of 50 years and above. Around $60 \%$ of the respondents were married. Even though the study engaged post graduate students but most of the students were full time students rather employed. The rest of the students were either govt. or private job holders. Around 55\% of the students were self-financed and the rest of them had scholarship. (Appendix)

In Australia male international students are double than their counter parts. The highest number of students falls in between 20 to 29 years of age and the second highest falls within the age of 30 to 39. Most of the students are married. Here most of the students are full time students. The number of self-financed students and that of scholarship holders are quite comparable. (Appendix)

In order to measure the reliability of an instrument Cronbach's alpha is the fundamental tool. If the value of Cronbach's alpha is more than 0.60 then it indicates the instruments as reliable(Malhotra, 2008). The table 1 
shows the overall reliability statistics in which overall Cronbach's alpha is .828 for overall instrument and that is satisfactory.

\section{Table 1. Overall Reliability}

\begin{tabular}{|l|l|}
\hline \multicolumn{2}{|l|}{ Reliability Statistics } \\
\hline Cronbach's Alpha & N of Items \\
\hline .828 & 40 \\
\hline
\end{tabular}

\section{Source: Author's Computation (2014)}

Factor analysis measures the interrelationships among the large number of composing variables. It determines the set of variables where there is the high interrelationship(Hair et al, 2010). It helps reducing the number of total items and selects the most relevant one under the specific construct or phenomena. On the contrary, few assumptions and preconditions are supposed to be satisfied before applying the factor analysis. Those assumptions help to confirm the fitness of data for applying the factor analysis.

It is already mentioned that the objective of factor analysis is to find the appropriate items of the specific constructs. In order to do so, the analysis has a comprehensive process. Overall factor analysis application is discussed broadly in the followings.

The table 2 shows that the sample is adequate for factor analysis as the $\mathrm{KMO}$ value is more than .60 and significant value of Bartlett's test of sphericity is good enough. All these indicate the study can carry on factor analysis. 
Table 2.KMO and Bartlett's Test

\begin{tabular}{|l|l|l|}
\hline \multicolumn{2}{|l|}{ KMO and Bartlett's Test } \\
\hline Kaiser-Meyer-Olkin Measure of Sampling Adequacy. & .815 \\
\hline \multirow{3}{*}{ Bartlett's Test of Sphericity } & Approx. Chi-Square & 2943.167 \\
\cline { 2 - 3 } & Df & 378 \\
\cline { 2 - 3 } & Sig. & .000 \\
\hline
\end{tabular}

\section{Source: Author's Computation (2014)}

Factor extraction is defined as a cluster or grouping of variables in distinctive factors. Eigen value is used as the most common criteria in order to choose the appropriate number of factors. Eigen value or latent root value 1 or greater determines the expected number of factors in the study (Malhotra, 2008). After running and revising the factor analysis several times, the final table has been shown below where total six factors are extracted. More than 60 percent of variance is explained with the help of the extracted factors in the dataset.

The entire variables are loaded in the rotated component matrix into six factors. Additionally, few of the items were also cross loaded under more than one construct. The rotated factor loadings define the possibility of the consequential factors.

\section{Table 3. Rotated Factor Matrix}

\begin{tabular}{|c|c|c|c|c|c|c|c|}
\hline \multirow{3}{*}{$\begin{array}{l}\text { Factor } \\
\text { Name }\end{array}$} & \multicolumn{7}{|c|}{ Rotated Component Matrix } \\
\hline & \multirow[t]{2}{*}{ Component Variables } & \multicolumn{6}{|c|}{ Component } \\
\hline & & 1 & 2 & 3 & 4 & 5 & 6 \\
\hline $\begin{array}{l}\text { Aca- } \\
\text { demic } \\
\text { Issues }\end{array}$ & & & & & & & \\
\hline $\mathrm{Al} 2$ & $\begin{array}{l}\text { Versatility of Academic } \\
\text { Programs }\end{array}$ & & .815 & & & & \\
\hline
\end{tabular}




\begin{tabular}{|c|c|c|c|c|c|}
\hline $\mathrm{Al} 3$ & Admission Process & & .834 & & \\
\hline $\mathrm{Al} 4$ & Quality of lectures & & .821 & & \\
\hline Al5 & $\begin{array}{l}\text { Lecturers' supportive } \\
\text { attitude }\end{array}$ & & .807 & & \\
\hline Al6 & Service of admin staff & & .789 & & \\
\hline \multicolumn{6}{|l|}{$\begin{array}{l}\text { Image } \\
\text { and } \\
\text { Prestige }\end{array}$} \\
\hline $\mathrm{IP}_{1}$ & $\begin{array}{l}\text { Image and prestige in } \\
\text { home country }\end{array}$ & & & .787 & \\
\hline $\mathrm{IP} 2$ & $\begin{array}{l}\text { Image and prestige in } \\
\text { host country }\end{array}$ & & & .784 & \\
\hline $\mathrm{IP} 3$ & $\begin{array}{l}\text { Image and prestige in- } \\
\text { ternationally }\end{array}$ & & & .754 & \\
\hline IP4 & $\begin{array}{l}\text { Continental image and } \\
\text { prestige }\end{array}$ & & & .783 & \\
\hline IP5 & $\begin{array}{l}\text { Wide recognition of the } \\
\text { institutions }\end{array}$ & & & .793 & \\
\hline \multicolumn{6}{|l|}{$\begin{array}{l}\text { Eco- } \\
\text { nomic } \\
\text { Consid- } \\
\text { eration }\end{array}$} \\
\hline $\mathrm{EC} 1$ & Cost of education & .840 & & & \\
\hline $\mathrm{EC} 2$ & $\begin{array}{l}\text { Scholarship opportunity } \\
\text { in University }\end{array}$ & .790 & & & \\
\hline EC4 & $\begin{array}{l}\text { Financial assistantship } \\
\text { from outside of the } \\
\text { university }\end{array}$ & .842 & & & \\
\hline $\mathrm{EC}_{5}$ & Cost of Living & .843 & & & \\
\hline EC6 & Fees reduction program & .841 & & & \\
\hline \multicolumn{6}{|l|}{$\begin{array}{l}\text { Infra- } \\
\text { struc- } \\
\text { ture }\end{array}$} \\
\hline IF1 & Physical infrastructure & & & & .795 \\
\hline $\mathrm{IF} 2$ & ICT facilities & & & & .730 \\
\hline IF3 & Library facilities & & & & .724 \\
\hline $\mathrm{IF} 4$ & Cafeteria & & & & .742 \\
\hline $\begin{array}{l}\text { Student } \\
\text { Satis- } \\
\text { faction }\end{array}$ & & & & & \\
\hline
\end{tabular}




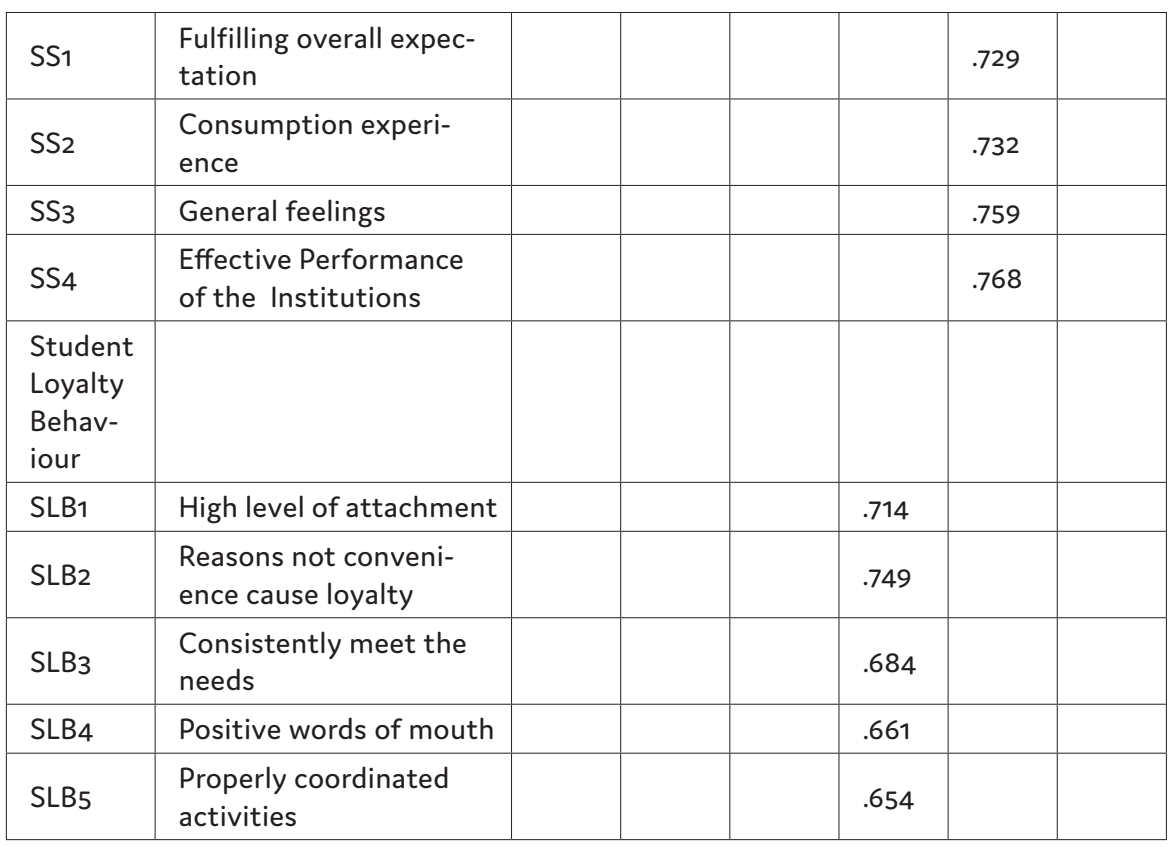

Source: Author's Computation (2014) 
Table 4. Total Variance Explained

\begin{tabular}{|c|c|c|c|c|c|c|c|c|c|}
\hline \multicolumn{10}{|c|}{ Total Variance Explained } \\
\hline \multirow{2}{*}{$\begin{array}{l}\text { Com- } \\
\text { po- } \\
\text { nent }\end{array}$} & \multicolumn{3}{|c|}{ Initial Eigenvalues } & \multicolumn{3}{|c|}{$\begin{array}{l}\text { Extraction Sums of } \\
\text { Squared Loadings }\end{array}$} & \multicolumn{3}{|c|}{$\begin{array}{l}\text { Rotation Sums of } \\
\text { Squared Loadings }\end{array}$} \\
\hline & Total & $\begin{array}{l}\% \text { of } \\
\text { Vari- } \\
\text { ance }\end{array}$ & $\begin{array}{l}\mathrm{Cu}- \\
\text { mu- } \\
\text { lative } \\
\%\end{array}$ & Total & $\begin{array}{l}\% \text { of } \\
\text { Vari- } \\
\text { ance }\end{array}$ & $\begin{array}{l}\mathrm{Cu}- \\
\text { mu- } \\
\text { lative } \\
\%\end{array}$ & Total & $\begin{array}{l}\% \text { of } \\
\text { Vari- } \\
\text { ance }\end{array}$ & $\begin{array}{l}\mathrm{Cu}- \\
\text { mu- } \\
\text { lative } \\
\%\end{array}$ \\
\hline 1 & 4.893 & 17.476 & 17.476 & 4.893 & 17.476 & 17.476 & 3.537 & 12.634 & 12.634 \\
\hline 2 & 3.323 & 11.866 & 29.342 & 3.323 & 11.866 & 29.342 & 3.524 & 12.585 & 25.219 \\
\hline 3 & 3.055 & 10.912 & 40.255 & 3.055 & 10.912 & 40.255 & 3.124 & 11.157 & 36.375 \\
\hline 4 & 2.554 & 9.121 & 49.376 & 2.554 & 9.121 & 49.376 & 2.510 & 8.963 & 45.339 \\
\hline 5 & 2.043 & 7.298 & 56.674 & 2.043 & 7.298 & 56.674 & 2.481 & 8.862 & 54.201 \\
\hline 6 & 1.639 & 5.853 & 62.527 & 1.639 & 5.853 & 62.527 & 2.331 & 8.326 & 62.527 \\
\hline & & & & & & & & & \\
\hline & & & & & & & & & \\
\hline
\end{tabular}

\section{Source: Author's Computation (2014)}

Rotated component matrix shows the meaningful factor rotation in the table 3. To avoid the cross loading under the multiple factors, the value of factor loading less than .40 or below must be suppressed(Sekaran, 2010). As each factor needs to be unique and distinct, after several running of the factor analysis the above rotated matrix shows the ultimate demonstration of items associated with the respective factors. Some of the items were excluded because of the cross loading.

Based on the theory and literatures of the study, final factors are Academic Issues, Economic Considerations, Image plus Prestige, Infrastructure, Student Satisfaction and Student Loyalty Behavior.

In SEM, critical ratio or C.R value 1.96 is used as the benchmark for testing the hypothesis. In order to establish the stronger relationship, the greater value is expected. C.R values of the research suggest that, all the constituting factors (independent and mediating variables) have the signi- 
ficant positive influence on student loyalty behavior except the direct relationship between Student Loyalty Behavior and Image and Prestige and the direct relationship between Student Loyalty Behavior and Academic Issues as because all the C.R values are greater than 1.96 except the C.R values for the above mentioned relationships.

After few modifications, the main model is improved. For an instance, CMIN/DF is less than 5 while RMSEA and CFI values are also in the range of cut off values (Hair et al., 2010). The measurement errors can be related as the correlations are logical (Figure 1). The result of the revised model: CMIN/ DF = less than 5, CFI=.924 and RMSEA .032, all these indicate a good fit of the CFA (Figure 1).

Therefore, it is found that the proposed model to measure student loyalty behavior through student satisfaction is fit with the given responses from the Malaysian and Australian higher learning institutions. Additionally, the tested values of the parameter estimates are significant and not involve any offending estimate. Further, the model is statistically appropriate and there is no contradiction with theoretical justifications and result is logical. As noted above, squared multiple correlation (SMC) shows the reliability of the variables and the variance in the endogenous variables are accounted by the predictors (Tabachinik and Fidell, 2007). 
Figure 1. Revised Baseline Model

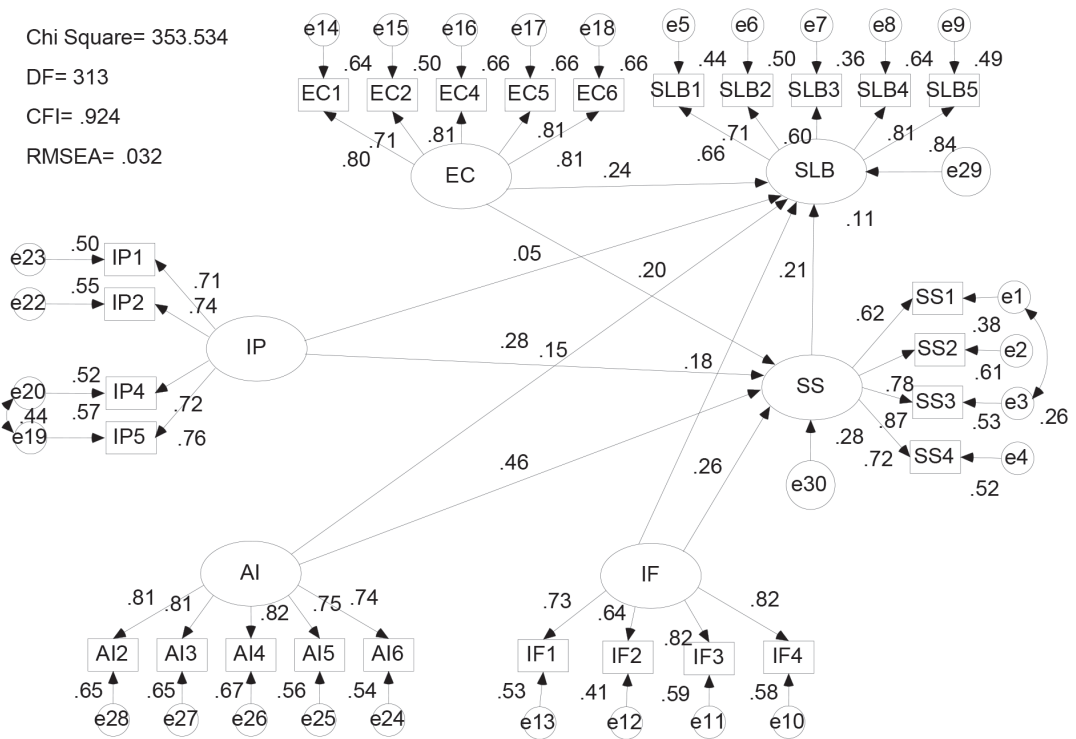

Source: Author's Computation (2014)

Table 5. Standard Regression Weight (Revised Baseline Model)

\begin{tabular}{|l|l|l|l|l|l|l|l|}
\hline & & & $\begin{array}{l}\text { Esti- } \\
\text { mate }\end{array}$ & S.E. & C.R. & $P$ & Label \\
\hline SS & $<---$ & Al & .313 & .056 & 5.590 & $\star \star \star$ & Accepted \\
\hline SS & $<---$ & EC & .128 & .044 & 2.937 & .023 & Accepted \\
\hline SS & $<---$ & IP & .102 & .049 & 2.102 & .036 & Accepted \\
\hline SS & $<---$ & IF & .122 & .047 & 2.595 & .030 & Accepted \\
\hline SLB & $<---$ & SS & .242 & .116 & 2.094 & .036 & Accepted \\
\hline SLB & $<---$ & Al & .058 & .068 & .853 & .393 & $\begin{array}{l}\text { Not Ac- } \\
\text { cepted }\end{array}$ \\
\hline SLB & $<---$ & EC & .125 & .063 & 1.984 & .045 & Accepted \\
\hline SLB & $<---$ & IP & .035 & .060 & .580 & .562 & $\begin{array}{l}\text { Not Ac- } \\
\text { cepted }\end{array}$ \\
\hline SLB & $<---$ & IF & .212 & .096 & 2.220 & .026 & Accepted \\
\hline
\end{tabular}

Source: Author's Computation (2014) 
One of the major objectives of the study is to find out whether there is any difference between the international students of Malaysian and Australian higher learning institutions, regarding the factors affecting their satisfaction and loyalty behavior. Therefore the ultimate hypothesis of the study is: Country of Origin has Moderating Effect on International Student Satisfaction towards Loyalty.

In order to investigate the moderating effect, SEM follows a particular process. First, data is divided on the basis of the responses of two different groups and saved under different group names. Afterwards, two separate AMOS models are developed by using two different data sets and labeled with different names and if there is no significant difference between the models, it will proceed for the next stage of invariance analysis. At last, Chi Square values for both Constrained and Unconstrained models including Degree of Freedom, the study calculates if the difference of Chi Square and Degree of Freedom for two groups is significant. If, it is not significant then it can be conferred that the two models are identical and the nature of respondents does not have any moderating effect on the study.

Table 6. Result of Multiple Group Modeling (Constrained Vs Unconstrained)

\begin{tabular}{|l|l|l|l|l|l|}
\hline Model & $X^{2}$ & Df & $\begin{array}{l}\text { Critical } \\
\text { value }\end{array}$ & $\Delta X^{2}$ & Sig \\
\hline Constrained & 717.589 & 628 & .905 & 1.142 & Not Sig \\
\hline $\begin{array}{l}\text { Uncon- } \\
\text { strained }\end{array}$ & 695.119 & 627 & & & \\
\hline
\end{tabular}

\section{Source: Author's Computation (2014)}

In this study, Figure 2 and 3 show the unique response of the two groups of respondents as international students in Malaysia and as international students in Australia. Based on these Figures, it is clear that there is no moderation seen. Therefore, it moves to the next stage of Invariance Analysis 
considering both Constrained and Unconstrained types of models in order to see if there is any difference between Chi Square values in according to the DF values which are significant. In Constrained model, all the hypothesized relationships are constrained. That means, relationships between the paths of Al to SS, EC to SS, IP to SS, IF to SS, SS to SLB, AI to SLB, EC to SLB, IP to SLB and IF to SLB are constrained associated with the static parameter values for both groups. If the critical value is less than the table value, then it is considered that the $\Delta X^{2}$ and $\Delta d f$ (Table 6), two models are not significantly different to each other (Hair et al., 2010). Therefore it means that Country of Origin does not moderate the proposed model of this study.

Conversely, these two groups are different in the aspects of specific paths and item loadings. For an example, the relationship between Student Satisfaction and Student Loyalty Behavior is more significant in Australia than that of Malaysia. Additionally, International Students in Malaysia think Academic Issues and Economic Considerations are more important for their satisfaction rather than the international students in Australia. Other factors are quite comparable to affect Student Loyalty Behavior. All the statistical paths of these two separate models are not identical. 
Figure 2. Unique Response of the International Students in Malaysia

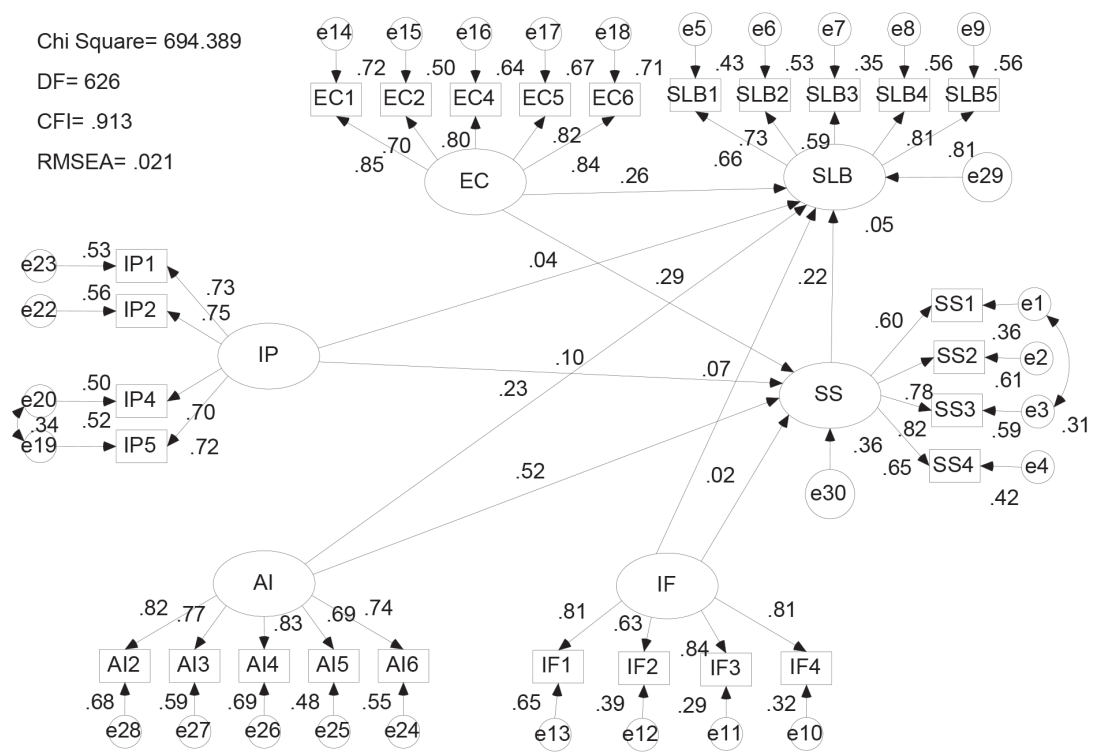

Source: Author's Computation (2014) 
Figure 3. Unique Response of the International Students in Australia

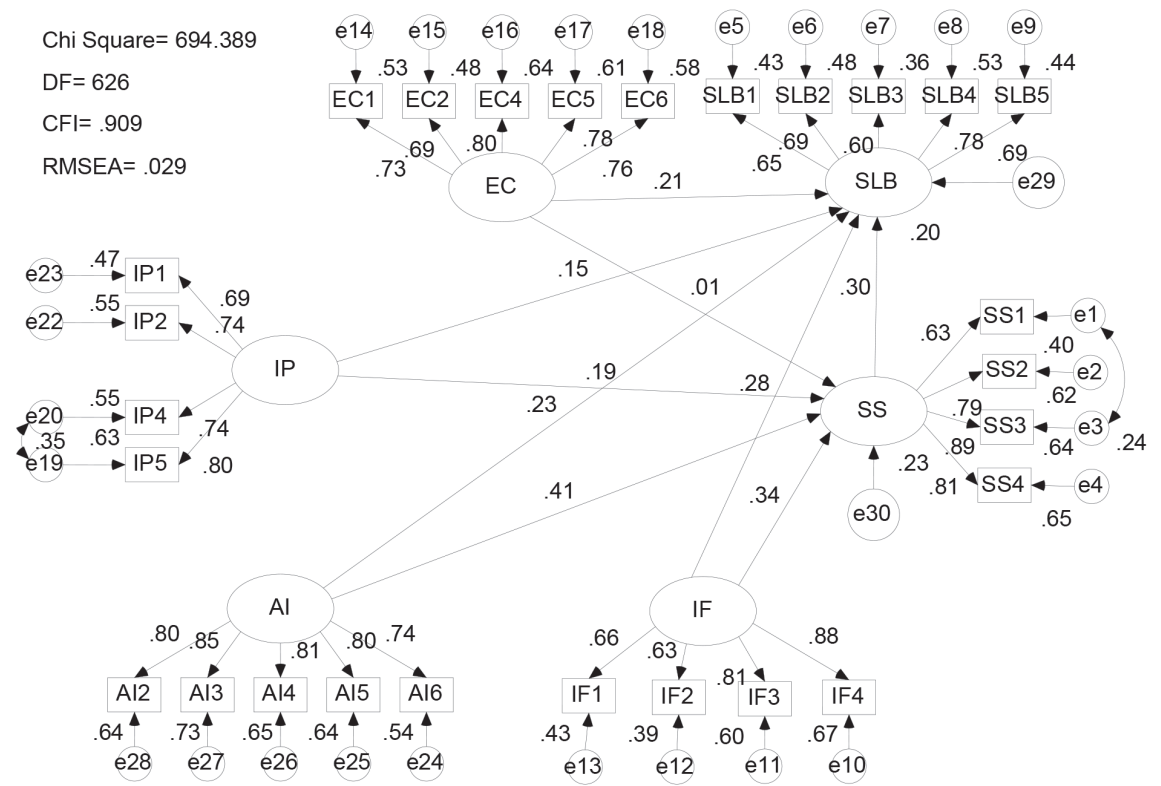

\section{Source: Author's Computation (2014)}

It can convey the proportion of variance among the constituting items of the constructs. For the analysis of expected level of convergent validity, certain conditions are needed to be fulfilled. At first, most of the factor loadings of the constructs should be greater or equal to .70. Secondly, the construct reliability should be greater than .60. At last, the average variance extracted (AVE) should be .50 or more. (Hair et al, 2010). Factor loadings values are greater than .70 in most of the cases. Further AVE values are also greater than .50. If the AVE value is closer to .50 (where total number of respondents is over 200), there is nothing wrong with the issue of convergent validity (Hair, 2010). Additionally, in the case of reliability, all the values are greater than .70 under each construct and the threshold value is .60.

Discriminant validity tests statistically whether two constructs differ to each other (Hair et al., 2010). To confirm this validity, average variance extracted under each construct is compared with the squared correla- 
tion ( $r$ square) with those of other constructs. If there is positive difference between AVE and $r$ square then the uniqueness of the constructs are ensured. In this case, AVE should be greater than the square multiple correlation value. In each case AVE is bigger than the squared multiple correlation value. Thus, discriminant validity is confirmed in the analysis and all constructs are unique. (Appendix)

\section{Conclusion}

This study is conducted in order to meet some objectives. These objectives may include, finding out the significant factors that affect international student satisfaction and loyalty behavior in Malaysia and also in Australia, measuring the significant level of relationship between international student satisfaction and their loyalty behavior in both countries and finding out the mediating effect of student satisfaction between the given factors and student loyalty behavior. As the study was conducted in two countries thus it gives an opportunity to compare between these two countries on the given issue. This is to find out the moderating effect on the whole process of factors affecting international student satisfaction with an extension of their loyalty behavior. Here, the moderating variable is country of origin (Malaysia/Australia). From this measure it is easy to find out whether there is any difference between these two countries and whether the difference is significant or not. By using Structural Equation Modeling (SEM), several results could be achieved. Based on several statistical and scientific researches and the results found by this study, a conclusion can be made.

It is found by the study that, international students of Malaysia and Australia treat the four factors significant while connecting them with their satisfaction level. There exists full or partial mediation of International Student Satisfaction between individual factors and International Student Loyalty Behavior except for one factor. Thus the study supports the role of mediation in the model. But there are slight differences between these two 
countries. Based on the Standard Regression Weight it is clear that, in Malaysia Academic Issues and Economic Considerations are more important rather than Image \& Prestige and Infrastructure to foreign students. Other factors are quite comparable in these two countries. Thus the moderating effect of country of origin is clear and concerning the overall difference it is non-significant.

\section{Implications and Recommendations for Future Research}

In the context of Malaysia this sort of study is not sufficient, even though it was very common in western culture. But day by day Malaysia has achieved a respectable position in the world market for its high quality and competitive higher education system. Additionally, the number of international student is increasing greatly. Therefore, the topic of the study where the core factor is international student has great value. In order to improve this sector and to sustain the credibility in the competitive world market, international student satisfaction and loyalty are most important issues.

Thus, the study has found which factors are more important to the foreign students for their satisfaction and loyalty so that policy makers can invest their time, money and effort for the betterment of those factors. On the other hand, the study has involved Australia, the country which has achieved third position in the international education market. By involving this country a good comparison can be made on this issue and the outcome of the research may lead to proper guidelines for Malaysia where the country can or try to hope a position like a developed country Australia in the international education market. Consequently, the study has both theoretical and practical significance as the findings of the research may fill the imperative research gaps that were identified in the literatures. 


\section{References}

Abe, J., Talbot, D.M., \& Geelhoed, R.J. (1998) Effects of a Peer Program on International Student Adjustment. Journal of College Student Development, 39(6), 539-547.

Anderson, E.W. (1998) Customer satisfaction and word of mouth. Journal of Service Research, 1 (1), 5-17.

Angell, R.J., Heffernan, T.W. and Megicks, P. (2008) Service quality in postgraduate education. Quality Assurance in Education, 16 (3), 236-54.

Arambewela, R. (2008) A Model of Student Satisfaction: International Postgraduate Students from Asia. Advances in Consumer Research, 8, 129-135.

Arambewela, R., \& Hall, J. (2009) An empirical model of international student satisfaction. Asia Pacific Journal of Marketing and Logistics, 21(4), 555-569. doi:10.1108/13555850910997599.

Astin, A. W. (1993) What matters in college? San Francisco: Jossey-Bass.

Baker, R.W., McNeil, O.V. and Sirky, B. (1985) Expectation and reality in freshmen: adjustment to college, Journal of Counselling Psychology, 32, 94-103.

Betz, E. L., Klingensmith, J. E., \& Menne, J. W. (1970) The measurement and analysis of college student satisfaction. Measurement and Evaluation in Guidance, 3, 110-118.

Black, J.S. and Gregersen, H.B. (1991) The other half of the picture: antecedents of spouse cross-cultural adjustment. Journal of International Business Studies, 3 (22), $461-77$. 
Burke, B.D. (1986) Experiences of overseas undergraduate students. Bulletin No. 18, University of New South Wales.

Carlborg, P., Kindström, D., \& Kowalkowski, C. (2014) The evolution of service innovation research: a critical review and synthesis. The Service Industries Journal, 34(5), 373-398.

Carter, S., \& Yeo, A. C. M. (2016) Students-as-customers' satisfaction, predictive retention with marketing implications: the case of Malaysian higher education business students. International Journal of Educational Management, 30(5), 635-652.

Chen, Y., Hasiao, C., \& Lee, W., (2005) How does student Satisfaction Influence Student Loyalty - From the Relationship Marketing Perspective. The Seventh National Educational Conference, Taiwan.

Cubillo-Pinilla, J.M., Zuniga, J., Losantos, I.S. and Sanchez, J. (2009) Factors influencing international students' evaluations of higher education programs. The Journal of American Academy of Business, 15 (1), 270-8.

Emory, C.W. and Cooper, D.R. (1991) Business Research Methods. Irwin Homeward.

Gay, L.R. (1992) Educational Research Competencies for Analysis and Application, 4th. Ed., New York: Macmillan.

Hair, J.F., Anderson, R.E., Tanthan, R.L. and Black, W.C. (1998) Multivariate Data Analysis, 5th. Ed., Uppple Saddle River, New Jersey: Prentice Hall.

Hair, J.F., Black, W.C., Babin, B.J., Anderson, R.E. and Tatham R.L. (2010) Multivariate data analaysis. New Jersey: Pearson Hall. 
Ham, L. and Hayduk, S. (2003) Gaining competitive advantages in higher education: analyzing the gap between expectations and perception of service quality. International Journal of Value-Based Management, 16 (3), 223-42.

Harvey, L. (2001) Student Feedback: A Report to the Higher Education Funding Council for England, Centre for Research and Quality. The University of Central England, Birmingham.

Hassanain, M.A. (2008) On the performance evaluation of sustainable student housing facilities. Journal of Facilities Management, 6 (3), 212-25.

Hooper, D., Coughlan, J., \& Mullen, M. (2008) Structural equation Modeling: Guidelines for Determining Model Fit. Electronic Journal of Business Research Methods, $6(1), 53-60$.

International Development Programs (IDP), Education Australia Pty Ltd. (2007), Global Student Mobility: An Australian Perspective Five Years on, IDP, Australia.

Israel, N. Jr (1990) The relationship of acculturation and acculturative stress to college environmental stress, college satisfaction, and self-esteem among Hispanic undergraduates at selected Ohio universities. PhD dissertation, Ohio State University, Columbus, $\mathrm{OH}$.

Jalali, A. (2011) Service Satisfaction: The Case of a Higher Learning Institution in Malaysia. International Education, 4(1), 182-193.

Kanji, G. K., Abdul Malek bin A.Tambi, \& Wallace, W. (1999) A comparative study of quality practices in higher education institutions in the US and Malaysia. Total Quality Management, 10(3), 357-371. 
Kamal, N., Yunus, Y., Zainal, A., \& Abdul, A. (2010) Motivation, Empowerment, Service Quality and Polytechnic Students' Level of Satisfaction in Malaysia. Journal of Business, 1(1), 120-129.

Kotler, P., \& Armstrong, G. (2001) Principles of Marketing. United States of America. Pearson Education.

Lascu, D., Ashworth, N., Giese, T., and Omar, M. (1995) The User Information Satisfaction Scale: International Applications and Implications for Management and Marketing. Multinational Business Review, 3 (2), 107-115.

Malhotra, N.K. (2004), Marketing Reserach, An Appplied Orientation, 4th. Edition, Pearson Education, Inc.

Malhotra, N.K. (2008) Marketing Research: An Applied Orientation. (4th. ed.), Pearson Education, Inc.

Ministry of Higher Education (MOHE) (2010) Education Malaysia - Malaysia Centre of Educational Excellence, www.educationmalaysia.gov.my/index. php?article1/4mohe.

Mullins, G., Qunintrell, N. and Hancock, L. (1995) The experiences of international and local students at three Australian Universities. Higher Education Research and Development, 14 (2), 201-31.

Najib, N. 'Ulyani M., Yusof, N. A., \& Abidin, N. Z. (2011) Student residential satisfaction in research universities. Journal of Facilities Management, 9(3), 200-212. doi:10.1108/14725961111148108

Parasuraman, A., Berry, L.L. and Zeithaml, V.A. (1991). Refinement and reassessment of the SERVQUAL scale. Journal of Retailing, 67 (4), 420-50. 
Rajah, D., \& Nadarajah, V. (August 8th, 2000) Go for quality: Musa suggests methods for varsities to improve. New Strait Time, 1.

Rasli, A., \&Naim, A. S. (2005) Pengurusan Teknologi. UTM Press.

Sekaran, U., and Bougie, R. (2010) Research methods for business: a skill building approach. Wiley, New York, NY.

Sohail, S.M. and Saeed, M. (2003) Private higher education in Malaysia: student satisfaction levels and strategic implications. Journal of Higher Education Policy and Management, 25 (2), 173-81.

Shahzad, A., Golamdin, A. G., \& Ismail, N. A. (2016) Opportunity and Challenges Using The Cloud Computing In The Case Of Malaysian Higher Education Institutions. International Journal of Management Science and Technology Information, 20, 1-18.

Shekarchizadeh, A., Rasli, A., \& Hon-Tat, H. (2011) SERVQUAL in Malaysian universities: perspectives of international students. Business Process Management Journal, 17(1), 67-81. doi:10.1108/14637151111105580

Shephard, K. (2008) Higher education for sustainability: seeking affective learning outcomes. International Journal of Sustainability in Higher Education, Vol. 9, Issue 1, 87-98.

Tabachnick, B.G., Fidell, L.S. (2001) Using Multivariate Statistics. Boston: Allyn and Bacon.

Weidemann, S. and Anderson, J.R. (1985) A conceptual framework for residential satisfaction. Home Environments: Human Behaviour and Environment, 8, 153-81. 
Wilkins, S., Balakrishnan, M.S., \& Huisman, J. (2012) Student choice in higher education: Motivations for choosing to study at an international branch campus. Journal of Studies in International Education, 16(5), 413-433.

Wu, P.L., Yeh, S.S., \& Woodside, A.G. (2014) Applying complexity theory to deepen service dominant logic: Configural analysis of customer experience-and-outcome assessments of professional services for personal transformations. Journal of Business Research, 67(8), 1647-1670. 


\section{Appendix}

\section{Sample Demographics (Malaysia)}

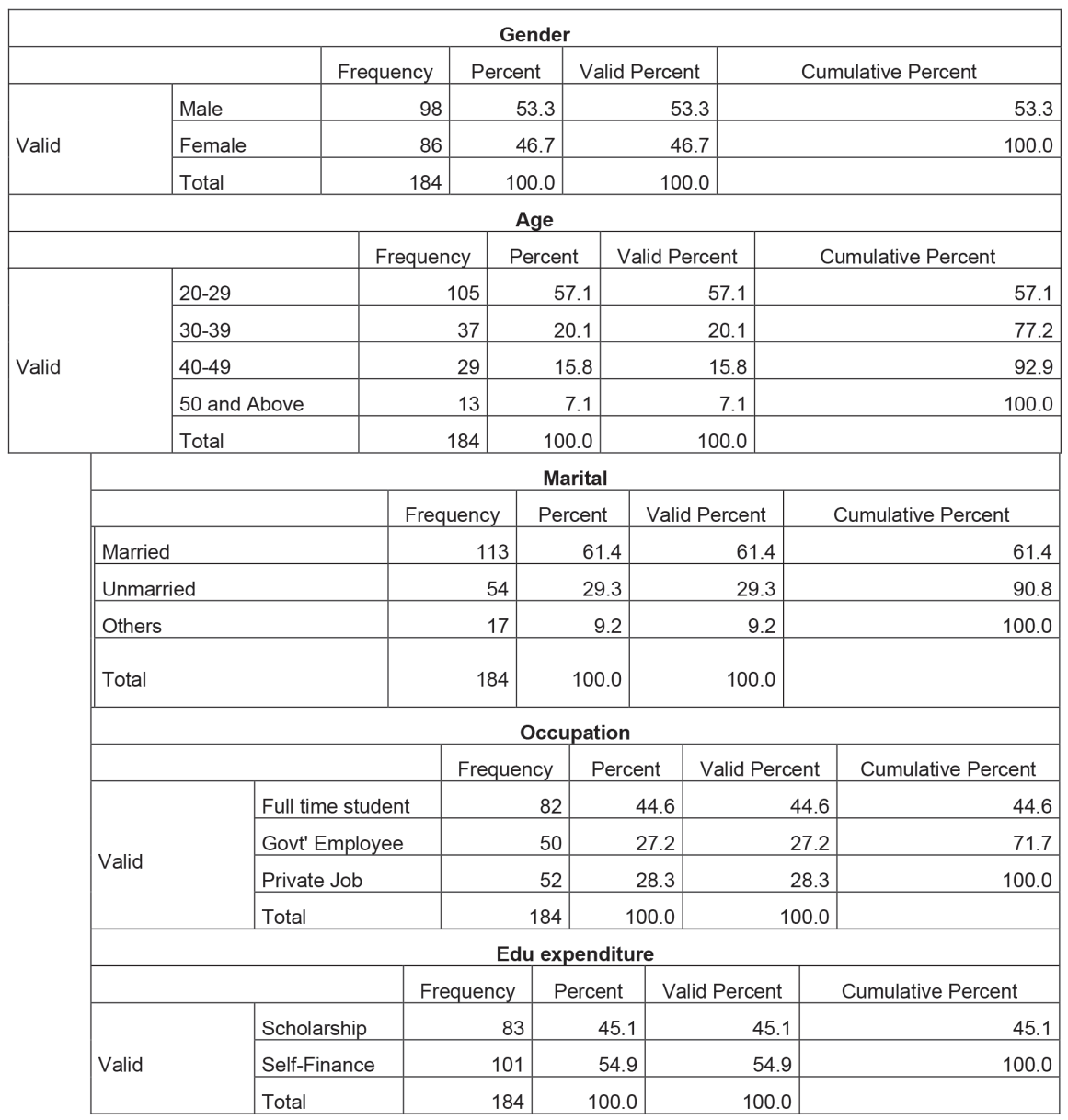

Source: Author's Computation (2014) 


\section{Sample Demographics (Australia)}

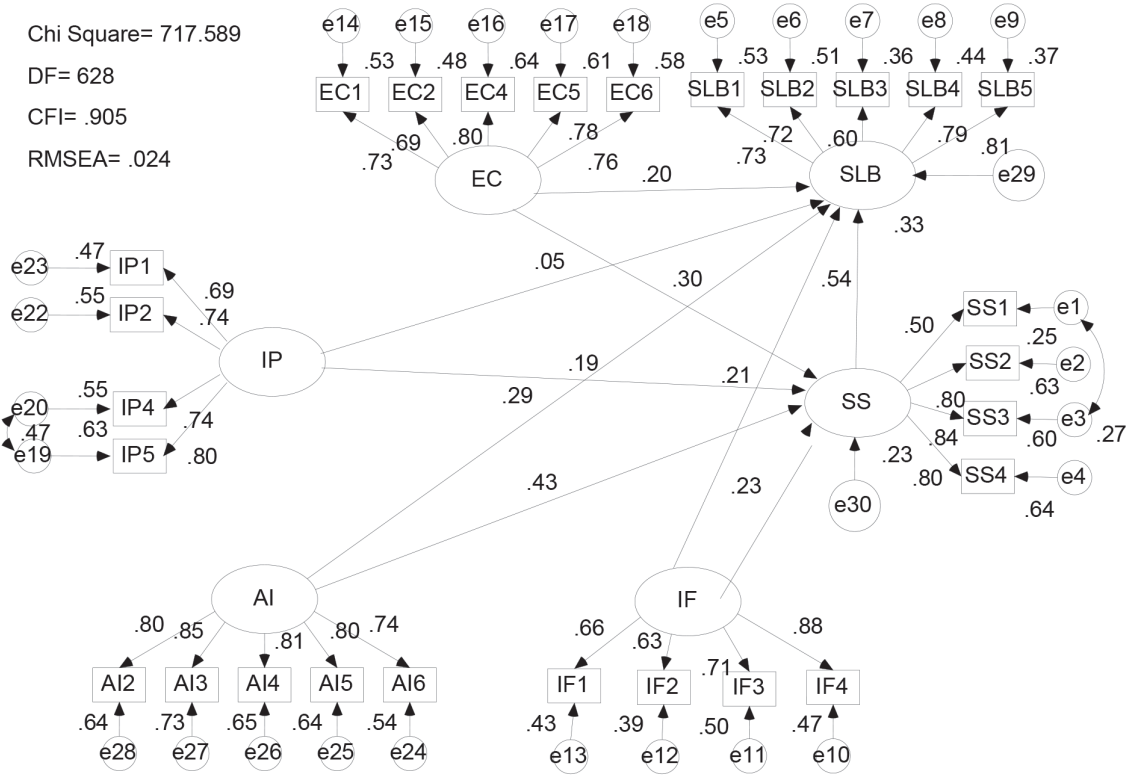


Figure 4. Constrained ModelSource: Author's Computation (2014)

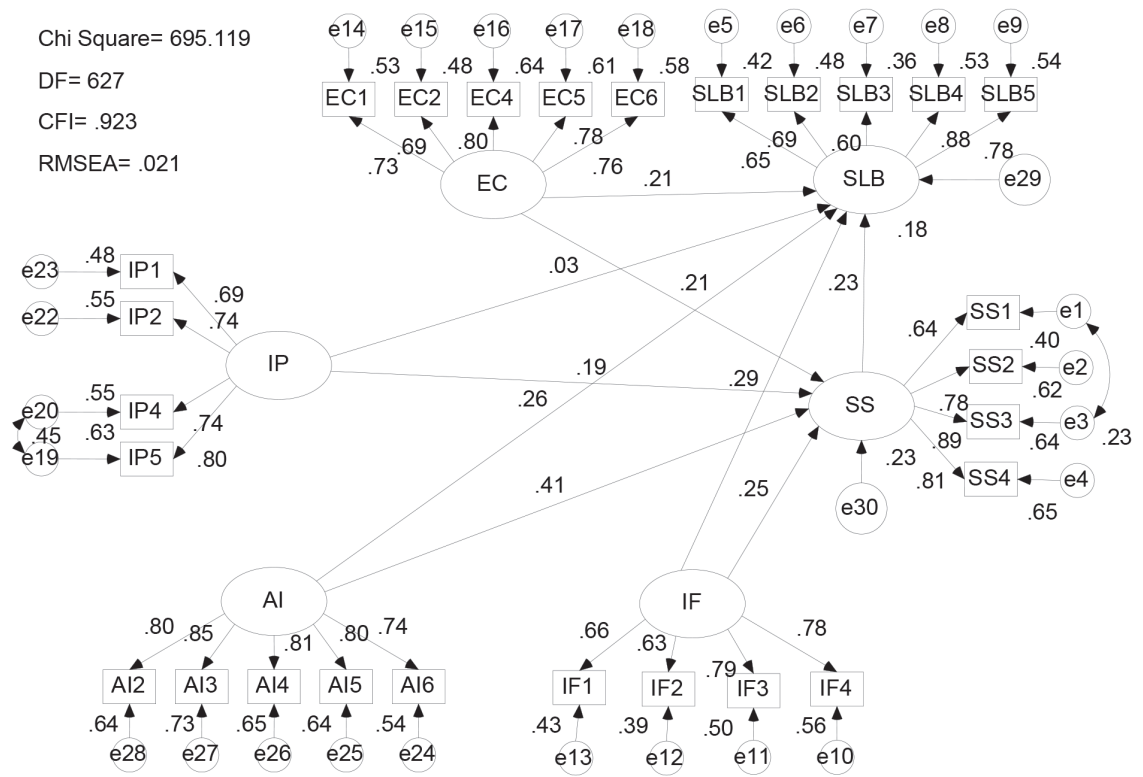


Figure 5. Unconstrained Model

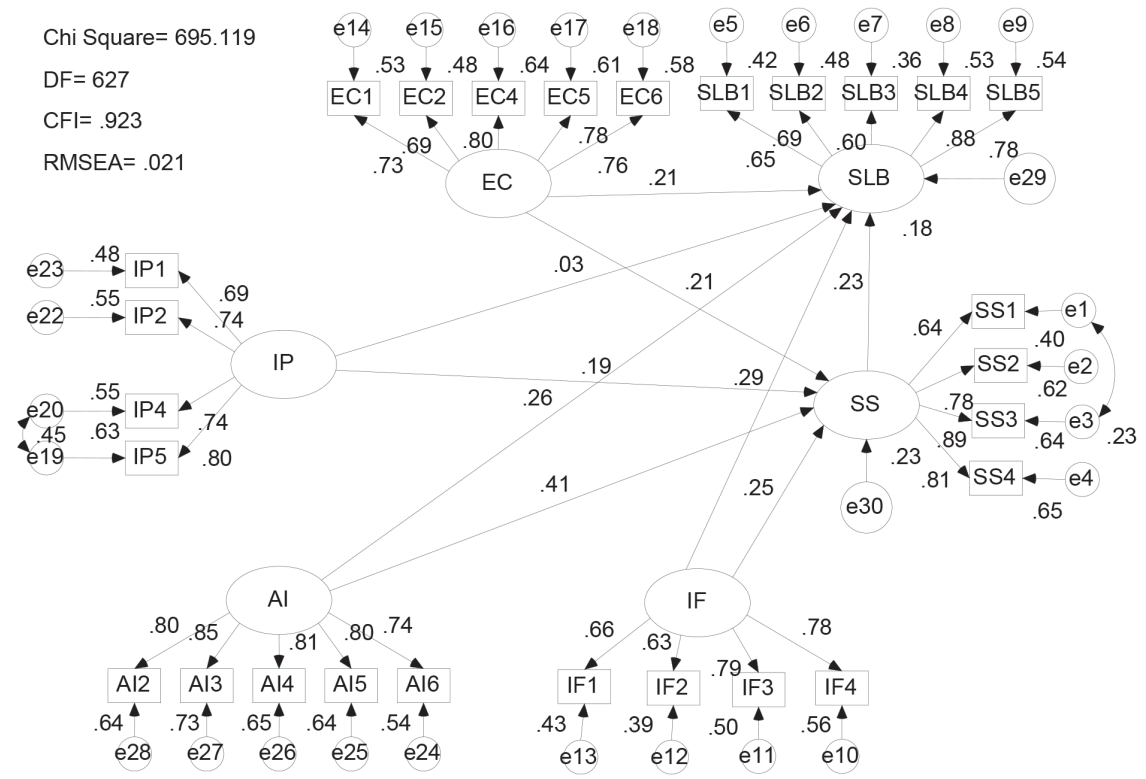

Source: Author's Computation (2014) 


\section{Factor Loadings, AVE and Construct Reliability Computation for the Constructs}

\begin{tabular}{|c|c|c|c|c|c|c|c|c|c|c|}
\hline & SS & & IF & & Al & & IP & & EC & \\
\hline & Loading & Square L & Loading & Square L & Loading & Square L & Loading & Square L & Loading & Square L \\
\hline L1 & 0.68 & 0.4624 & 0.73 & 0.5329 & 0.89 & 0.7921 & 0.71 & 0.5041 & 0.8 & 0.64 \\
\hline L2 & 0.78 & 0.6084 & 0.69 & 0.4761 & 0.81 & 0.6561 & 0.75 & 0.5625 & 0.71 & 0.5041 \\
\hline L3 & 0.84 & 0.7056 & 0.82 & 0.6724 & 0.82 & 0.6724 & 0.77 & 0.5929 & 0.81 & 0.6561 \\
\hline L4 & 0.72 & 0.5184 & 0.84 & 0.7056 & 0.74 & 0.5476 & 0.75 & 0.5625 & 0.81 & 0.6561 \\
\hline L5 & & & & & 0.74 & 0.5476 & & & 0.81 & 0.6561 \\
\hline & & & & & & & & & & \\
\hline Sum & 3.02 & $\quad 2.2948$ & & 2.387 & & 3.2158 & & 2.222 & 3.94 & 3.1124 \\
\hline S.Sum & 9.1204 & 5.266107 & & 5.697769 & & 10.34137 & & 4.937284 & 15.5236 & 9.687034 \\
\hline 1-L1 & & 0.5376 & & 0.4671 & & 0.2079 & & 0.4959 & & 0.36 \\
\hline $1-L 2$ & & 0.3916 & & 0.5239 & & 0.3439 & & 0.4375 & & 0.4959 \\
\hline $1-L 3$ & & 0.2944 & & 0.3276 & & 0.3276 & & 0.4071 & & 0.3439 \\
\hline 1-L4 & & 0.4816 & & 0.2944 & & 0.4524 & & 0.4375 & & 0.3439 \\
\hline 1-L5 & & & & & & 0.4524 & & & & 0.3439 \\
\hline SUM & & 1.7052 & & 1.613 & & 1.7842 & & 1.778 & & 1.8876 \\
\hline & & & & & & & & & & \\
\hline AVE & & 0.5737 & & 0.59675 & & 0.64316 & & 0.5555 & & 0.62248 \\
\hline & & & & & & & & & & \\
\hline C.R & & 0.842484 & & 0.779367 & & 0.852856 & & 0.735231 & & 0.836919 \\
\hline
\end{tabular}

Note: Here, AVE = Average Variance Extracted and C.R = Construct Reliability. S. Sum= Square Sum. For every case AVE is greater than .50 and C.R is greater than .60 show good level of convergent validity.

Source: Author's Computation (2014)

AVE vs. Squared Multiple Correlation Value of the Constructs

\begin{tabular}{|l|l|l|l|l|l|}
\hline \multicolumn{6}{|c|}{ AVE VS Squared Multiple Correlation value of the constructs } \\
\hline & SS & IF & Al & IP & EC \\
\hline SS & 0.57 & 0.0441 & 0.2401 & 0.0361 & 0.1156 \\
\hline IF & 0.21 & 0.59 & 0.0289 & 0.1156 & 0.1444 \\
\hline AI & 0.49 & 0.17 & 0.64 & 0.1444 & 0.3025 \\
\hline IP & 0.19 & 0.34 & 0.38 & 0.55 & 0.1849 \\
\hline EC & 0.25 & 0.11 & 0.66 & 0.43 & 0.62 \\
\hline
\end{tabular}

Note: this table shows that all the predictors (constructs that predict the DV) are unique in nature. Here, Diagonal values represent AVE where Correlation and Multiple Correlation of the constructs are placed below and above respectively.

\section{Source: Author's Computation (2014)}


